\title{
Imaging Immunoassay in Negative: Surface-Catalysed Chemiluminescence for the Detection of Pregnancy Hormones in Artificial Saliva
}

\author{
Kevin J. Wright, ${ }^{1}$ Zeid O. Oiaidha, ${ }^{1}$ Daniel P. Love, ${ }^{1}$ \\ Mohammed Aljohani, ${ }^{1,2}$ Gillian M. Greenway, ${ }^{1 *}$ Jay D. Wadhawan ${ }^{1,3^{*}}$ \\ ${ }^{1}$ School of Mathematics \& Physical Sciences, The University of Hull, \\ Cottingham Road, Kingston-upon-Hull HU6 7RX, United Kingdom. \\ ${ }^{2}$ Chemistry Department, College of Science, The University of Taif, \\ Airport Road, Al Hawiyah, Taif 26571, Saudi Arabia \\ ${ }^{3}$ School of Engineering \& Computer Science, The University of Hull, \\ Cottingham Road, Kingston-upon-Hull HU6 7RX, United Kingdom.
}

To be submitted to New J. Chem.

${ }^{*}$ Corresponding authors.

E.mail: g.m.greenway@hull.ac.uk (GMG); j.wadhawan@hull.ac.uk (JDW) 


\begin{abstract}
A novel and rapid (45 min), quantitative chemiluminescence-based, surface immunoassay is reported for the quantitative detection of progesterone and œstriol in artificial saliva. The detection limits for these pregnancy hormones are 2.3 and $2.5 \mathrm{pg} \mathrm{mL}^{-1}$, respectively. The assay is based on the use of ferrocenetagged, monoclonal antibodies immobilised on a surface, so that the oxidised ferricenium catalyses the reaction between luminol and hydrogen peroxide. The immunoassay is performed in negative, such that increasing the antigen concentration gives rise to decreasing light intensity that is observed, and is unaffected by antibody orientation on the surface. This affords a method of calibration that is readily translated to pregnancy hormone detection in a primary point-of-care environment. Biomolecules with similar structures to these pregnancy hormones found in saliva are demonstrated not to interfere with the immunoassay.
\end{abstract}

Key words: Chemiluminescence, visual immunoassay, pregnancy hormones, luminol/hydrogen peroxide. 


\section{Introduction}

Immunoassays are widely regarded as a technique to detect biochemical analytes that are present in trace amounts. ${ }^{1}$ For "dipstick" sensing pathways, monoclonal antibodies are usually immobilised onto a solid surface. ${ }^{2}$ Although documented procedures are available for the antibody immobilisation process, it is often challenging to undertake quantitative analysis at low antigen concentrations using such protocols, owing to the irreproducible nature of the surface modification. For example, the commonly deployed method of silanisation of a glass or plastic surface with (3-aminopropyl)triethoxysilane followed by antibody immobilisation using a glutaraldehyde linker suffers from poor reproducibility, ${ }^{3-5}$ owing to batch-to-batch differences of glutaraldehyde and its self-polymerisation. ${ }^{6}$ Moreover, such surface-confined immunoassays are affected by antibody orientation; the ideal scenario of the antigen binding fragment (Fab) region being readily accessible for interaction with the analyte. ${ }^{1}$

In this work, we develop a protocol for quantitatively monitoring antigen concentrations at antibody-modified surfaces, where antibody orientation is not an issue, ${ }^{7,8}$ using the generation of chemiluminescence as the detection signal. Typically, chemiluminescence-based immunoassay allows for a high sensitivities, with measurements of antigen concentration in the sub-nanogramme per millilitre level possible, ${ }^{2}$ with the reaction between luminol and hydrogen peroxide catalysed by horseradish peroxidase being most common. ${ }^{9}$ In the latter, electron transfer catalysis through switching between $\mathrm{Fe}^{\mathrm{III}}$ and $\mathrm{Fe}^{\mathrm{II}}$ redox states in the enzyme, ${ }^{10}$ enables chemiluminescence. Since the active site within the enzyme is buried within the protein, the efficiency of the luminol/hydrogen peroxide reaction could be increased through the use of $\mathrm{Fe}^{3+}, 11$ ferricyanide, ${ }^{12}$ or ferricenium ions molecular catalysts. ${ }^{13,14}$ The latter species are readily electrochemically generated from ferrocene, which itself is a common label for electroimmunoassay. ${ }^{7}$

Accordingly, in this work, we immobilise ferrocene-labelled antibodies onto a transparent electrode surface, electrochemically oxidise the ferrocene-tag and monitor chemiluminescence both in the absence, and presence, of various 
concentrations of antigen in artificial saliva. Saliva is considered to be an excellent medium for biomarker detection, ${ }^{15}$ since clinical samples may be collected simply, safely and non-invasively, without incurring discomfort to the patient. ${ }^{16}$ In this work, the antigen is either progesterone or œstriol, as these are pregnancy biomarkers, for which monoclonal antibodies with high affinity have been developed. ${ }^{17}$ Progesterone is involved in conception, so that low concentrations can give rise to early indications of potential miscarriage, preterm birth and the health of the developing fœtus; ${ }^{18,19}$ œstriol likewise is important for fœetal development and the onset of labour. ${ }^{20}$ Progesterone concentrations in saliva during pregnancy are reported as around $7 \mathrm{pg} \mathrm{mL}^{-1}$ (during the follicular phase), ${ }^{21} 140 \mathrm{pg} \mathrm{mL}^{-1}$ (during the luteal phase), ${ }^{21}$ and with an upper threshold of $22500 \mathrm{pg} \mathrm{mL}^{-1}$. Furthermore, it has been reported that there is a significant correlation between saliva progesterone and serum progesterone during the menstrual cycle, ${ }^{23}$ whilst a weak correlation exists during late preganancy. ${ }^{24}$ For œstriol, the clinically relevant upper threshold is 25 $5 \mathrm{ng} \mathrm{mL} \mathrm{m}^{-1}$. It has been found that strong correlations between blood serum and saliva levels exist during normal ${ }^{26,27}$ and third trimester pregnancy. ${ }^{28}$ Moreover, it has been demonstrated that the ratio of œstriol-to-progesterone in the body may enable clinical insight for the onset of labour. ${ }^{29}$ It thus follows that, fast, easy-to-use, reliable and inexpensive methods for the quantitative detection of both these antigens empowers the development of point-of-care devices to monitor the state of pregnancy.

We first develop and characterise a new concept imaging immunoassay, before examining its use for the detection of both progesterone and œstriol in artificial saliva. We have chosen not to study real saliva samples since we wish merely to demonstrate our method of immunoassay - a challenge with saliva compared with serum is that the target hormones are at lower levels, typically $1 \%$ of the serum concentration. ${ }^{30}$ Although our monitoring of free hormones in artifcical saliva overcomes problems associated with biologically inactive, proteinconjugated hormones in blood serum, we ignore real matrix effects and interferences, such as endogenous peroxidases which could quench the chemiluminescent signal. 


\section{Experimental}

\subsection{Chemical and Biochemical Reagents}

Mouse monoclonal anti-progesterone [pg. 53]: reactivity human (isotype IgG1, ab9187, $1 \mathrm{mg} \mathrm{mL}^{-1}$ ), and rabbit monoclonal anti-œstriol [EPPTXR3] (ab221960, $1.01 \mathrm{mg} \mathrm{mL}^{-1}$ ) antibodies were purchased from Abcam. For the experiments reported in Figure 5, the antibody used was mouse, monoclonal, anti-cardiac troponin T antibody (ab8295, $1 \mathrm{mg} \mathrm{mL}^{-1}$ ) purchased from Abcam. Progesterone, œstriol, testosterone, œstradiol, and œstrone were purchased from SigmaAldrich in the purest grade commercially available, and used as received. 4Nitrobenzene diazonium tetrafluoroborate (Fast Red GG salt), tetrabutylammonium perchlorate (TBAP), ferrocenecarboxaldehyde (FcCHO), , sodium borohydride $\left(\mathrm{NaBH}_{4}\right)$, Tween 20 and luminol were obtained from Sigma. Hydrogen peroxide (20 vol, $>6 \% \mathrm{w} / \mathrm{v}$ ), hydrochloric acid, potassium chloride, sodium hydroxide, ethanol, acetonitrile, $\mathrm{N}, \mathrm{N}$-dimethylformamide (DMF) and potassium carbonate were obtained from Fisher-Scientific. Vitamin $\mathrm{D}_{3}$ was purchased from Alfa Aesar. Water, with a resistivity of $18.2 \mathrm{M} \Omega \mathrm{cm}$, was obtained from an Elgastat system. Aqueous buffer solution was phosphate buffered saline (PBS) at pH 7.4, prepared by dissolving one phosphate tablet (supplied from Sigma-Aldrich) containing $137 \mathrm{mM} \mathrm{NaCl}, 2.7 \mathrm{mM} \mathrm{KCl}$ and $10 \mathrm{mM}$ phosphate in $200 \mathrm{~mL}$ deionised water. N-hydroxysulfosuccinimide (sulfo-NHS, $5 \mathrm{mM}, \quad 2.2 \mathrm{mg}$ ) and N-(3-dimethylaminopropyl)-N'-ethylcarbodiimide hydrochloride (EDC, $2 \mathrm{mM}, 0.8 \mathrm{mg}$ ) were purchased from Sigma-Aldrich and both dissolved in $10 \mathrm{mM}$ PBS (2 mL) immediately prior to use. All other chemicals were purchased from Sigma-Aldrich (UK) in the highest purity grade commercially available and used without further purification. Artificial saliva was prepared as described by West et $a l^{31}$ and consisted of deionised water containing $\mathrm{NaCl}\left(1.954 \mathrm{~g} \mathrm{~L}^{-1}\right), \mathrm{NH}_{4} \mathrm{NO}_{3}\left(0.328 \mathrm{~g} \mathrm{~L}^{-1}\right), \mathrm{KH}_{2} \mathrm{PO}_{4}\left(0.639 \mathrm{~g} \mathrm{~L}^{-1}\right), \mathrm{KCl}$ $\left(0.202 \mathrm{~g} \mathrm{~L}^{-1}\right)$, sodium salt of uric acid $\left(0.021 \mathrm{~g} \mathrm{~L}^{-1}\right)$, potassium citrate $\left(0.308 \mathrm{~g} \mathrm{~L}^{-1}\right)$, urea (0.198 $\left.\mathrm{g} \mathrm{L}^{-1}\right)$, sodium salt of lactic acid $\left(0.146 \mathrm{~g} \mathrm{~L}^{-1}\right)$ and bovine submaxillary gland mucin Type I-S (30 $\left.\mathrm{g} \mathrm{L}^{-1}\right)$. 


\subsection{Instrumentation}

Electrochemical studies were performed in a modified three-electrode set-up with a tin-doped indium oxide (ITO) coated glass working electrode (CB-50INCUV, sheet resistance 5-15 $\Omega$, dimensions $7 \times 50 \times 0.7 \mathrm{~mm}$, Delta Technologies Ltd., USA). A defined area was prepared with Fisherclark WS5002 self adhesive paper reinforcement rings (determined using a travelling microscope to be of diameter $6 \mathrm{~mm}$ ), with one end used for electrical connection via application of copper tape. Up to three individual electrode areas were prepared per electrode.

Electrochemical measurements were made in a $70 \mu \mathrm{L}$ sample droplet with a nickel wire counter electrode and a saturated calomel reference electrode (SCE, Hach). All potentials are reported here against this reference, unless otherwise stated. Measurements were controlled by a $\mu$-AUTOLAB-type-III or Autolab PGSTAT101 potentiostat.

Chemiluminescence analysis was undertaken using a QHY6 charge coupled device camera (CCD, QHXCCD, USA) fitted with a high resolution pixel lens (8 mm, Computar, USA), and recorded using EZCAP 3.21 software (QHXCCD, USA). Measurements were made within a dark box. Prior to measurement, the antibody-modified surface was placed below the camera with a focussed image to record the background and subtract this from the experimental signal. Analysis of the resulting chemiluminescence photographs was performed using Image J software, where an average pixel intensity measurement was taken across the entire image.

All measurements were undertaken at ambient temperature (293 $\pm 2 \mathrm{~K})$.

\subsection{Synthesis of Ferrocene-Labelled Antibodies}

Antibodies were chemically labelled with ferrocene through the coupling scheme reported previously:7,8,32 $10 \mu \mathrm{L}$ of neat antibody were diluted to $200 \mu \mathrm{L}$ with 10 mM PBS (pH 7.4) and the $\mathrm{pH}$ adjusted to $\mathrm{pH} \sim 9$ by addition of 5 wt.\% potassium carbonate, with subsequent dilution with a $100 \mathrm{mg} \mathrm{mL}^{-1}$ solution of ferrocene carboxaldehyde (FcCHO) in DMF (20 mg in $200 \mu \mathrm{L})$, such that the FcCHO was in 
excess. This was followed by incubation at ambient temperature for $30 \mathrm{~min}$ to form the imine, and subsequently reduced with sodium borohydride (2.2 $\mathrm{mg}$ ), and incubated at ambient temperature for $10 \mathrm{~min}$ in order to form the secondary amine. The solution $\mathrm{pH}$ was adjusted to $\mathrm{pH} \sim 7$ using $0.1 \mathrm{M} \mathrm{HCl}$. Excess tag and solvent were removed from the ferrocene-conjugated antibody product after reaction by centrifugation and washed with $10 \mathrm{mM}$ PBS (12 krpm for 20min, followed by twice washing with PBS at $12 \mathrm{krpm}$ for 5 mins, using Vivaspin 500 centrifugal filters purchased from GE Healthcare, Sweden). Ultimately $400 \mu \mathrm{L}$ of the purified and concentrated ferrocene-conjugated antibody (at $25 \mu \mathrm{g} \mathrm{mL}^{-1}$ ) was obtained and stored within a refrigerator at $277 \mathrm{~K}$ until immediately prior to use.

\subsection{ITO Surface Modification with Amine Groups}

ITO electrodes were cleaned prior to modification with isopropanol. Amine modification of the electrode surface was achieved through electrochemical reduction of $2 \mathrm{mM}$ 4-nitrobenzene diazonium tetrafluoroborate in 0.1 M TBAP$\mathrm{MeCN}$ for the period of three reduction-oxidation cycles $(+0.7 \mathrm{~V}$ to $-0.4 \mathrm{~V})$ at $0.1 \mathrm{~V} \mathrm{~s}^{-1}$ to yield a nitrobenzene modified electrode, followed by six-electron, sixproton reduction to afford the amine, aqueous ethanol containing $0.1 \mathrm{M} \mathrm{KCl}$ $(90: 10, v / v)$ from $+0.4 \mathrm{~V}$ to $-1.25 \mathrm{~V} v$ s. SCE through three redox cycles at $0.1 \mathrm{~V} \mathrm{~s}^{-1}$.

\subsection{Bio-Conjugation of Ferrocene Labelled Antibodies to ITO Surface}

The immobilisation of antibody on the electrode surface was achieved through the coupling of carboxylic acid groups of the antibody to the primary amine groups of the phenylamine-modified ITO electrode surface via an amide linkage, in a manner reported previously. ${ }^{7,8}$ The $400 \mu \mathrm{L}$ aliquot of ferrocene-conjugated antibody was mixed with the same volume of activation buffer ( 2 mM EDC and 5 $\mathrm{mM}$ sulfo-NHS in $10 \mathrm{mM}$ PBS) for $15 \mathrm{~min}$ to activate the carboxy terminal of the antibody. Subsequently, $30 \mu \mathrm{L}$ of this solution was applied to the amine functionalized ITO electrode and stored at $277 \mathrm{~K}$ for 18 hours, after which the electrodes were washed with 0.1 vol.\% Tween 20 in 10 mM PBS, followed by PBS to remove unbound antibody, before drying under $\mathrm{N}_{2}$ stream. The electrodes 
were used immediately, or stored in $10 \mathrm{mM}$ PBS at $277 \mathrm{~K}$ until use. Typical storage times ranged from $24-48 \mathrm{~h}$.

\subsection{Hormone Measurement}

First, any non-specific binding sites on the modified ITO surface were blocked by the addition of $20 \mu \mathrm{L}$ of 1 wt. \% BSA-10mM PBS, pH 7.0 for $30 \mathrm{~min}$ at room temperature. Following this, the modified electrodes were rinsed with 0.1 vol.\% Tween 20 in 10 mM PBS followed by PBS. All electrodes were then conditioned in a $70 \mu \mathrm{L}$ PBS droplet using cyclic voltammetry at $0.1 \mathrm{~V} \mathrm{~s}^{-1}$ for three consecutive scans in the range $-0.05-+0.6 \mathrm{~V} v$ s. SCE. The ferrocene tags were then electrochemically oxidised using a $0.01 \mathrm{~V} \mathrm{~s}^{-1}$ scan rate, sweeping in the same range, but stopping after the oxidation wave, to afford the oxidised tag (ferricenium).

Chemiluminescence measurements were undertaken through first recording a background image, and then adding a $70 \mathrm{~mL}$ PBS droplet containing $10 \mathrm{mM}$ luminol, $10 \mathrm{mM}$ hydrogen peroxide and $0.1 \mathrm{M} \mathrm{NaOH}$ to the surface, and then recording an image. After this, the antibody-modified electrodes were incubated in known $30 \mu \mathrm{L}$ of known concentrations of antigen in either $10 \mathrm{mM}$ PBS or artificial saliva for particular time periods $(15,30$ and $60 \mathrm{~min}$ ) at room temperature (50-60\% relative humidity). After incubation, the electrodes were rinsed with Tween 20 and PBS, followed by drying in a nitrogen stream, to remove any loosely bound antigen. The electrodes were then subject to a reexamination of the chemiluminescence measurement in PBS. Interference studies in artificial saliva were undertaken using $20 \mathrm{ng} \mathrm{mL}^{-1}$ of the interfering species, and incubated for $30 \mathrm{~min}$, all other protocols remaining the same. 


\section{Results and Discussion}

We first characterise the ferrocene-tagged antibodies in terms of the number of ferrocene moieties sprinkled over the antibody surface and the surface density of antibodies immobilised on the electrode surface, before examining the use of these for catalysing the reaction between luminol and hydrogen peroxide.

\subsection{Characteristisation of Ferrocene-Tagged Antibodies}

The characterisation of ferrocene-conjugated anti-progesterone antibodies in PBS by UV-visible spectrophotometry revealed peak absorbances in the region 300-350 nm and at $454 \mathrm{~nm}$ (q.v. Figure 1a). As expected from the Lambert-Beer law, these were directly proportional to antibody concentration at low antibody concentration, affording an extinction coefficient of $16.7 \mathrm{~mL} \mathrm{mg}^{-1} \mathrm{~cm}^{-1}$ (Figure $1 b)$.
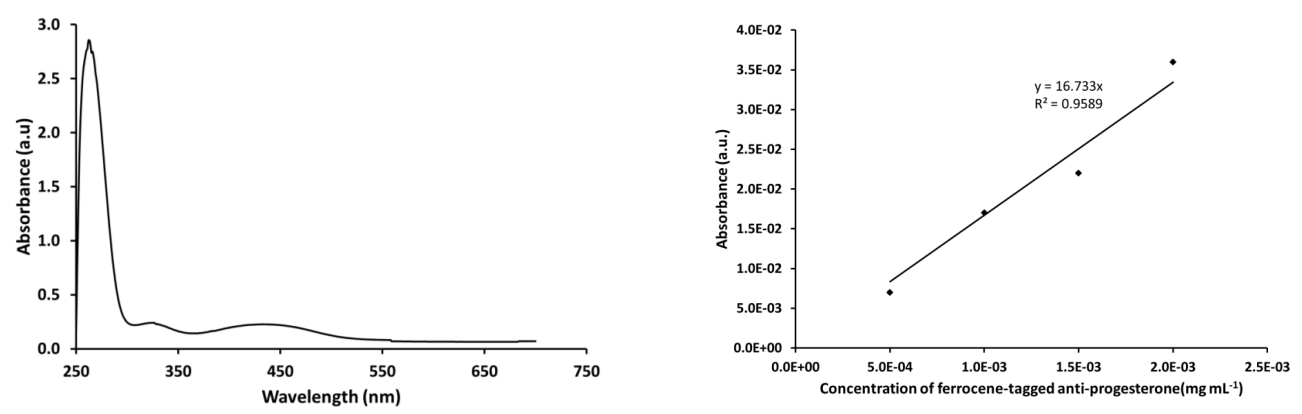

Figure 1: (a, left) UV-visible spectrum of ferrocene-tagged anti-progesterone antibodies in PBS at a the nascent concentration of conjugated antibodies of $25 \mu \mathrm{g} \mathrm{mL}^{-1}$; (b, right) Beer-Lambert calibration plot (at $454 \mathrm{~nm}$ ) for ferrocene-tagged anti-progresterone antibodies in the concentration range $0.5 \leq$ [antibody] $/ \mu \mathrm{g} \mathrm{mL}-1 \leq 2.0$.

Similarly, ferrocenecarboxaldehyde in PBS afforded an extinction coefficient (at wavelengths between $440-460 \mathrm{~nm}$ ) of $1.30 \mathrm{~mL} \mathrm{mg}^{-1} \mathrm{~cm}^{-1}$. Thus, assuming that only the ferrocene group absorbs at $454 \mathrm{~nm}$ in Figure 1, the average number of ferrocene moieties conjugated per antibody is estimated as between 12-13. This is almost double that estimated by Matsunga et al.,32. using goat anti-human IgG antibodies, with the likely sources of error being the uncertainty in the number of free primary amine residues in both antibodies, particularly at the paratopes, and in the assumed nascent concentration of conjugated antibodies in $\S 2.3$ (25 $\left.\mu \mathrm{g} \mathrm{mL}^{-1}\right)$. We next seek to quantify the number of antibodies immobilized on the electrode surface. 
We have demonstrated that voltammetric interrogation ferrocene-tagged antibodies immobilized through the platform developed on ITO electrodes can be treated as essentially electrochemically reversible at low scan rates. ${ }^{7,8}$ Figure 2 illustrates a linear sweep voltammogram of the immobilized ferrocene-labelled antibodies at a scan rate of $10 \mathrm{mV} \mathrm{s}^{-1}$, after cyclic voltammetric conditioning using three consecutive cycles at $100 \mathrm{mV} \mathrm{s}^{-1}$.

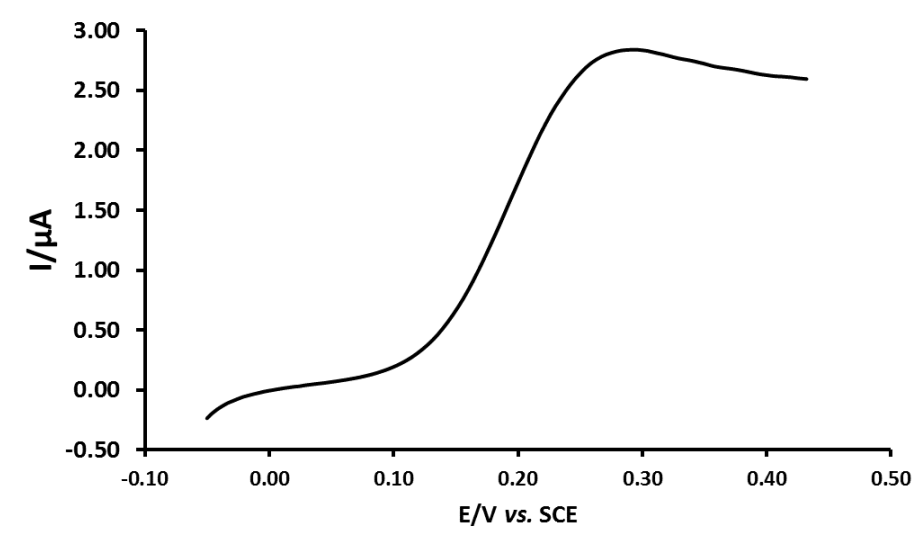

Figure 2: Linear sweep voltammogram (at $0.01 \mathrm{~V} \mathrm{~s}^{-1}$ ) corresponding to the oxidation of ferrocene-labelled anti-progesterone antibodies immobilised on an ITO electrode.

The broad but well-defined voltammetric wave with peak potential of $+0.25 \mathrm{~V} v s$. SCE is indicative of oxidation of the ferrocene labels (Fc) to ferricenium $\left(\mathrm{Fc}^{+}\right)$:

$$
F c-e^{-} \rightleftarrows F^{+}
$$

Assuming all ferrocene tags contribute to the wave, the charge under the wave $(1.04 \mu \mathrm{C})$, together with the estimate of ferrocene tags per antibody, affords an antibody density on the electrode of $c a .2 .9 \times 10^{-12} \mathrm{~mol} \mathrm{~cm}^{-2}$. Further, under the assumption of close-packing of monolayer antibodies on the nanostructured surface, these results afford an antibody diameter of around $8.5 \mathrm{~nm}$, which is approximately in agreement with the reported size of typical monoclonal IgG antibodies. $^{33}$ Taken together, this suggests that the primary source of discrepancy in the number of ferrocene moieties per antibody to be due to the different number of primary amine functional groups in both proteins.

We next investigate the ability of the ferricenium-based surface to catalyse the 
chemiluminescence between luminol and hydrogen peroxide.

\subsection{Surface-Based Chemiluminescence for Immunoassay}

The electrochemical oxidation of the immobilised ferrocene-conjugated antibodies depicted in Figure 2 enables the electrochemical generation of a surface-confined $\mathrm{Fe}$ III catalyst for the luminol $/ \mathrm{H}_{2} \mathrm{O}_{2}$ chemiluminescent reaction. ${ }^{34-38}$ Figure 3, panel (a) illustrates typical results of the electrochemically oxidised surface in the presence of an equimolar luminol $/ \mathrm{H}_{2} \mathrm{O}_{2}$ alkaline solution after $200 \mathrm{~s}$, where it is readily seen that the large surface density of antibodies and the high number of ferrocene tags enable an efficient and almost uniform generation of light over the disc surface.
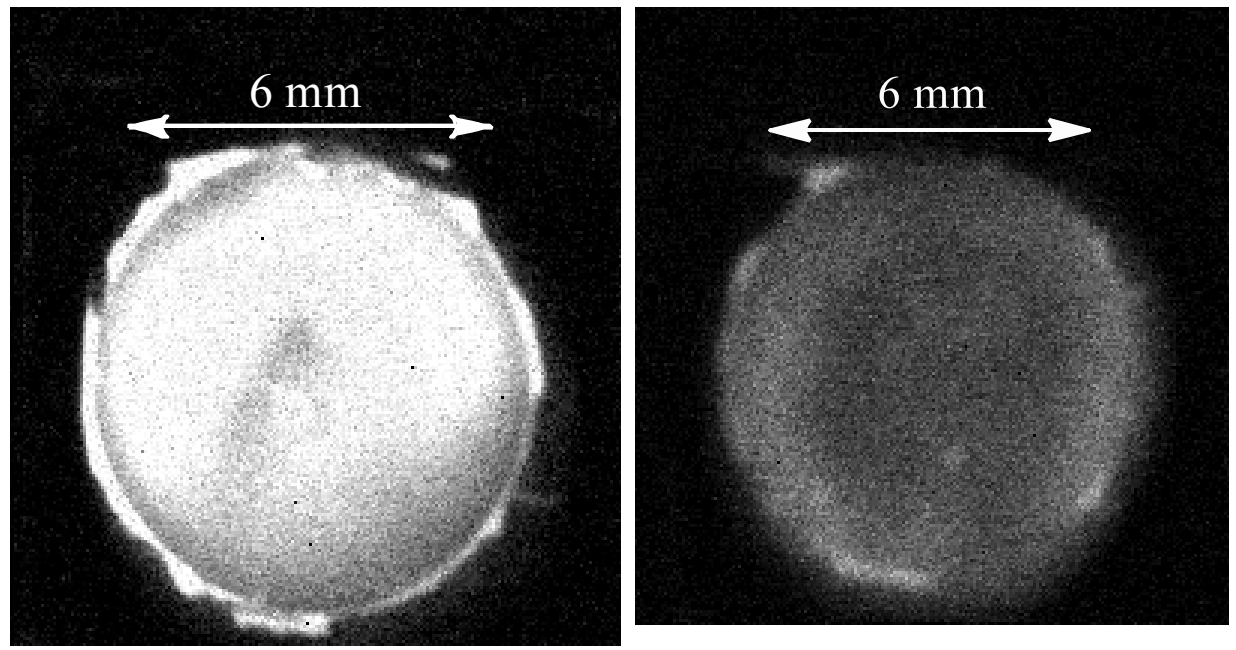

Figure 3: Chemiluminescence images (exposure time $200 \mathrm{~s}$ ) at ferricenium-labelled antiprogesterone antibodies immobilised on an ITO electrode surface immersed in $10 \mathrm{mM}$ hydrogen peroxide, $10 \mathrm{mM}$ luminol and $0.1 \mathrm{M}$ aqueous sodium hydroxide (a, left) immediately prior to, and

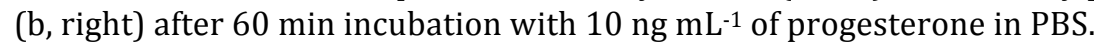

Following Schiffrin and Wilson, ${ }^{13,14}$ we propose that the electrochemically oxidised form of the redox tag (ferricenium) acts as the heterogeneous catalyst for the chemiluminescent reaction between hydrogen peroxide and luminol (see ESI 1 for the proposed reaction mechanism). The oxidised form of ferrocene is unstable through reaction with both oxygen ${ }^{39}$ and chloride. ${ }^{40}$ Thus, incubation of the surface in aqueous aerobic solutions can lead to a decrease in the performance of the catalyst at short periods of time. Evidence for this is given in Figures 4 and 5 , where it is seen that increasing the storage time of the ferricenium species in PBS, or other aqueous electrolytes, leads to a first to decrease in the observed chemiluminescence, and, after two days incubation in 
chloride electrolytes, actually leads to an large increase in the observed chemiluminescence intensity. These results are explained by the catalyst (ferricenium) breaking down in the presence of chloride to $\mathrm{FeCl}_{4}$, which is considered to be a more efficient catalyst for the reaction between hydrogen peroxide and luminol. The breakdown of the catalyst in saliva is less of an issue compared with PBS, as the chloride concentration is in the former (typically $\sim 30 \mathrm{mM})^{31}$ is between four and five times smaller than in PBS (140 mM).

a)

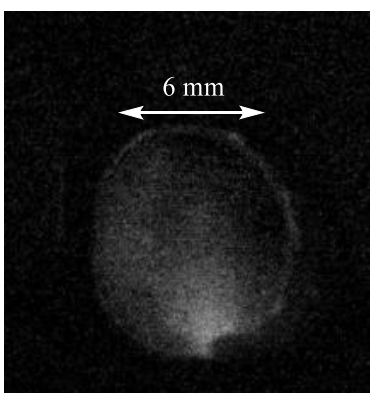

c)

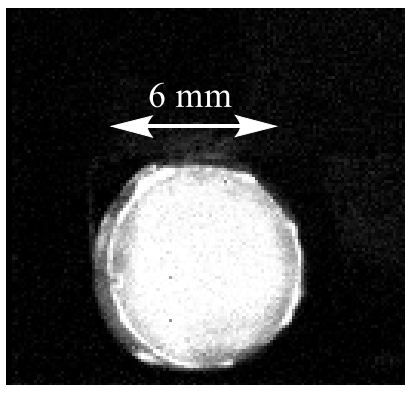

b)

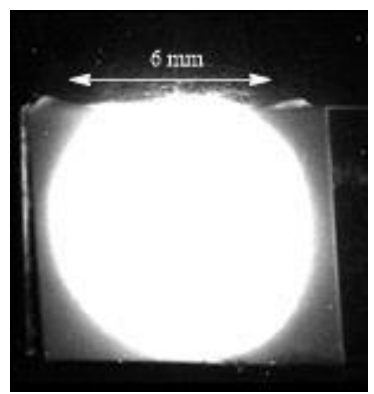

d)

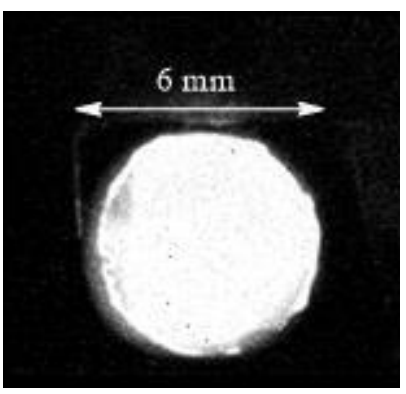

Figure 4: Effect of storage of ITO-immobilised ferricenium-labelled antibodies in PBS on the chemiluminescence intensity. Chemiluminescence images (exposure time $200 \mathrm{~s}$ ) at ferrocenelabelled anti-progesterone antibodies immobilised on an ITO electrode surface immersed in $10 \mathrm{mM}$ hydrogen peroxide, $10 \mathrm{mM}$ luminol and $0.1 \mathrm{M}$ aqueous sodium hydroxide (a) before electrochemical oxidation of the ferrocene to ferricenium, (b) immediately after ferrocene oxidation in PBS, (c) 60 min after ferrocene oxidation, and (d) $24 \mathrm{~h}$ after ferrocene oxidation. In (c) and (d), the electrode surface was stored in PBS when not tested for chemiluminescence. The different sizes of the observed discs arises from the different magnifications used to capture the image. 


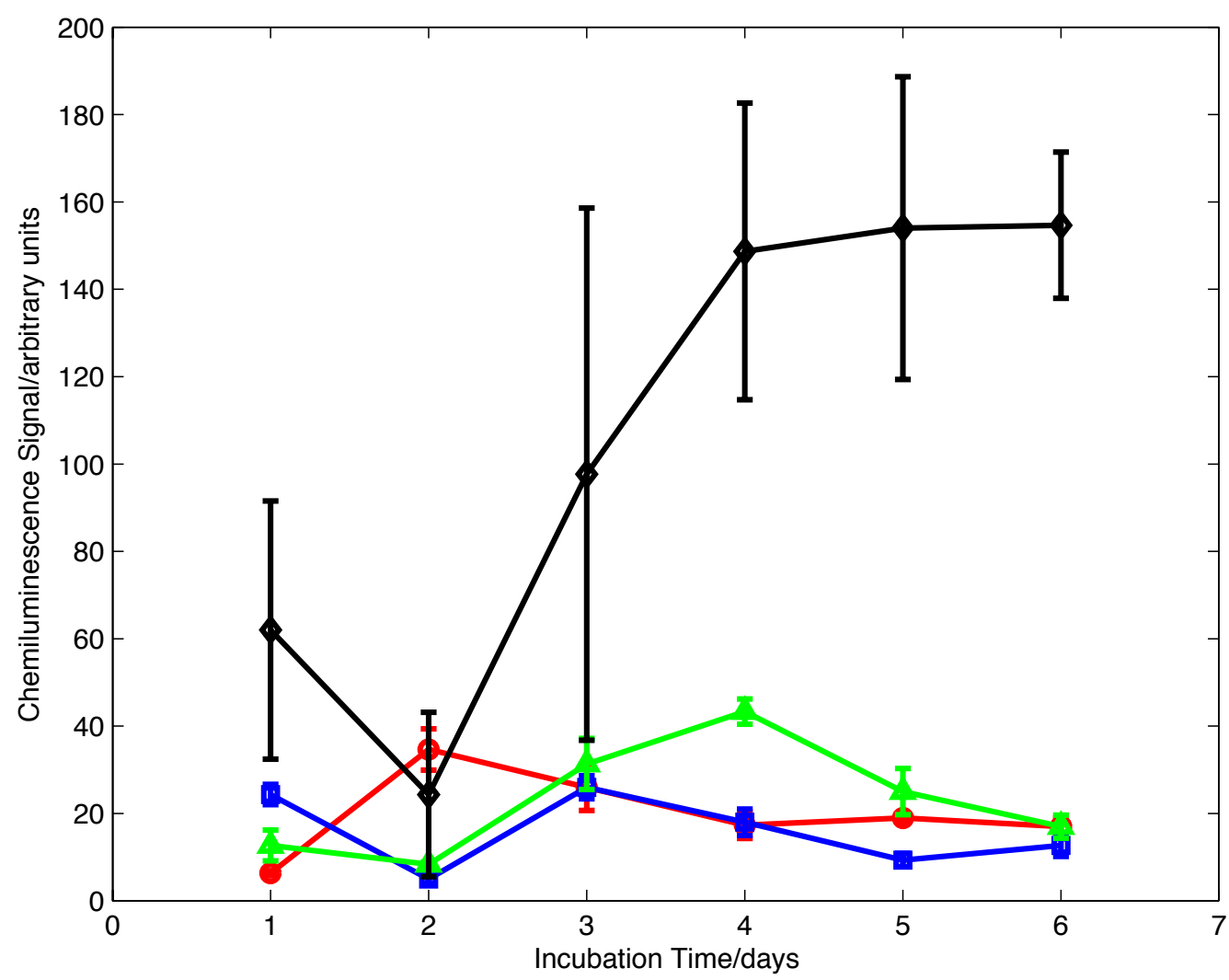

Figure 5: Effect of incubation time (without antigen) in aqueous aerobic electrolytes on the observed chemiluminesce of ferricenium-tagged antibodies immobilised on an ITO surface. The data reported are the absolute chemiluminescent intensity average of three spots (assed from images acquired using a $200 \mathrm{~s}$ exposure time using luminol and hydrogen peroxide concentrations of $10 \mathrm{mM}$ ), with the error bars representing one standard deviation. Key: water (red circles), $10 \mathrm{mM}$ PBS (blue squares), $10 \mathrm{mM} \mathrm{NaHCO}_{3}$ (green triangles), $1.0 \mathrm{M} \mathrm{KCl}$ (black diamonds). Lines showing trends are included merely to guide the eye.

Optimisation studies (see ESI 2) identified the following conditions for maximum chemiluminsecent signal: $200 \mathrm{~s}$ CCD exposure time and equal concentrations of luminol and hydrogen peroxide at $10 \mathrm{mM}$. Accordingly, all subsequent experiments were undertaken under these conditions.

It follows that since the chemiluminescence intensity is proportional to the surface coverage of catalyst, and because the ferrocene tags are predominantly located on the antibody paratopes, ${ }^{7,8}$ the blocking of the ferricenium moieties from the aqueous solution through antibody complexation with antigen should reduce the surface density of the chemiluminescence catalyst, resulting in lower amounts of chemically generated light. This is observed in Figure 3, panel (b): incubation for $60 \mathrm{~min}$ with $10 \mathrm{ng} \mathrm{mL} \mathrm{m}^{-1}$ antigen causes a major reduction in the light generated across the entire antibody-modified surface. Accordingly, we 
report the extent of antigen binding to the antibody-modified surface $(\theta)$ through the ratio of the overall light intensities (S), in a manner tantamount to the "taring" of a balance:

$$
\theta=1-\frac{(S)_{\text {antigen }}}{(S)_{\text {no antigen }}}
$$

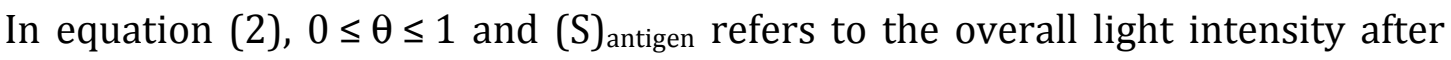

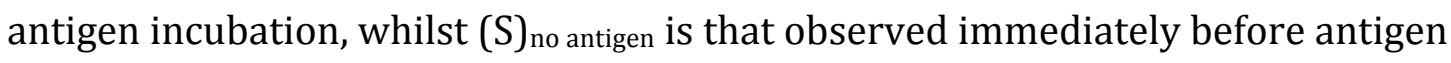
incubation. Thus, the variation of the light intensity with antigen concentration affords an exquisite route to immunoassay in negative: higher light intensities are expected for lower antigen concentrations. We next describe the use of this sensing protocol for immunoassay.

\subsection{Imaging Immunoassay of Progesterone and OEstriol in Saliva}

The imaging immunoassay strategy developed above was employed for the detection of both progesterone and œstriol in both PBS and artificial saliva. Figure 6 illustrates binding curves of global blocking fraction against antigen incubation time for progesterone and œstriol at electrodes modified with antiprogesterone and anti-œstriol antibodies, respectively, in both PBS (panel (a)) and artificial saliva (panel (b)). These data were obtained through the treatment of the overall chemiluminescence observed after a $200 \mathrm{~s}$ exposure time both before and after incubation with the antigen for various time periods. It is clear that the binding curves, which show increasing blockage of the light signal with incubation time and with initial antigen concentration in the range $10^{-2} \leq$ [antigen]/ng mL $\mathrm{n}^{-1} \leq 10^{2}$, have the expected shape. However, these do not reach equilibrium binding even for the largest combination of antigen concentration and incubation times investigated (60 $\mathrm{min}$ ), as expected for small antigenic molecules. Since the light intensity measurements were not obtained under steady-state conditions, and optimised only for the surface in the absence of antigen, it is inappropriate to extract thermodynamic and kinetic factors for the antigen-antibody complexation process from these data. Nevertheless, even at the smallest incubation times studied $(15 \mathrm{~min})$, it is clear that this visual 
immunoassay enables discrimination of antigen concentration over five orders of magnitude, q.v. Figure 6, panel c, with linear ranges of the analytical signal at $60 \mathrm{~min}$ incubation times for progesterone over the range $0.1-100 \mathrm{ng} \mathrm{mL}^{-1}$ (Pearson's product-moment correlation coefficient of 0.9273), and for œstriol over the range $0.01-100 \mathrm{ng} \mathrm{mL}^{-1}$ (Pearson's product-moment correlation coefficient of 0.9854), encouraging this methodology for pregnancy hormone detection. Matrix effects do not appear to be apparent.
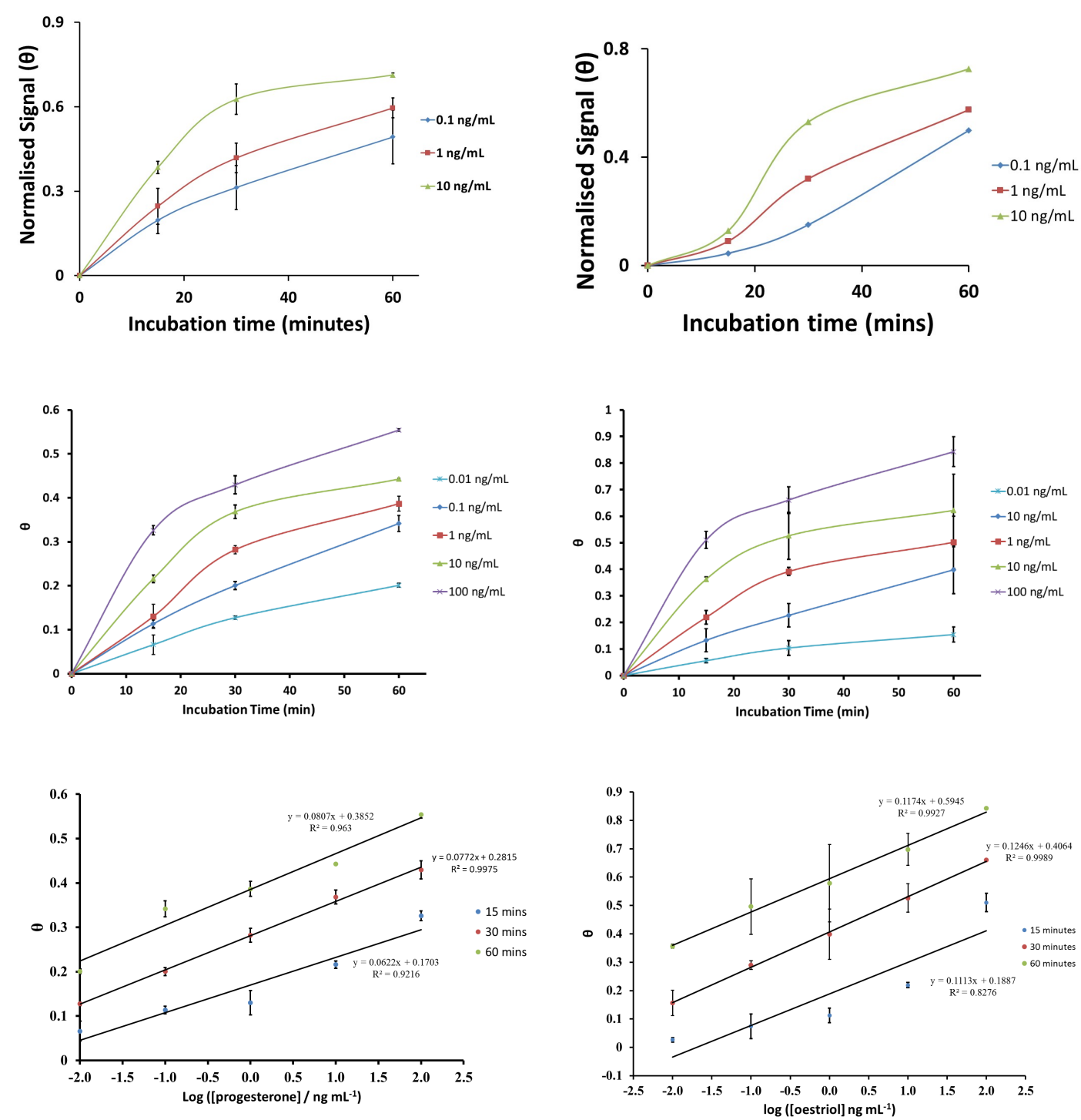

Figure 6: Time-dependent antigen-binding curves extracted from chemiluminescence images

(10 mM luminol, $10 \mathrm{mM} \mathrm{H}_{2} \mathrm{O}_{2}$ and $0.1 \mathrm{M}$ aqueous $\mathrm{NaOH}$, exposure time of $200 \mathrm{~s}$, over five repeats) with antigen incubation in PBS (a,top) and artificial saliva (b, middle), reanalysed to afford antigen calibration curves in artificial saliva (c, bottom), for antigen concentrations in the range $0.01 \leq$ [antigen] $/ \mathrm{ng} \mathrm{mL}^{-1} \leq 100.0$, at ferricenium-labelled anti-progesterone (i, left), or antiœstriol (ii, right) antibody modified ITO surfaces. In (a) and (b), the solid lines merely serve to guide the eye through the data points. The error bars represent one standard deviation. 
Based on the data in Figure 6, the quantifiable detection limits (at $30 \mathrm{~min}$ incubation time) are $0.1 \mathrm{ng} \mathrm{mL}^{-1}$ for both progesterone and œstriol in PBS, and $0.01 \mathrm{ng} \mathrm{mL}^{-1}$ for both antigens in artificial saliva. From the data in Figure $6 \mathrm{c}$, the limits of detection of both hormones in artificial saliva are calculated to be $2.4 \mathrm{pg} \mathrm{mL}^{-1}$ (progesterone) and $2.5 \mathrm{pg} \mathrm{mL}^{-1}$ (œstriol), based on $3 \mathrm{~s}_{\mathrm{b}}+$ average background signal, ${ }^{41}$ which augers well for using this method for clinically relevant samples.

In order to determine the extent of salivary interferences with similar structures to progesterone (testosterone and vitamin $\mathrm{D}_{3}$ ) and œstriol (œstradiol and œstrone), tests were undertaken to quantify the response of the antibodymodified electrode. In these tests, $20 \mathrm{ng} \mathrm{mL}^{-1}$ of the potential interfering species (concentrations that are substantially larger than present in clinical context ${ }^{42,43}$ ) were incubated in PBS for 30 min, followed by washing and immunoassay. The results are reported in Figure 7, where it is seen that for the anti-progesterone modified electrode, structurally similar molecules exhibit coverages that are around seven times smaller than that for progesterone, whilst structurally similar molecules to œstriol give rise to coverages at the anti- œstriol modified electrode that are about five times smaller than œstriol.
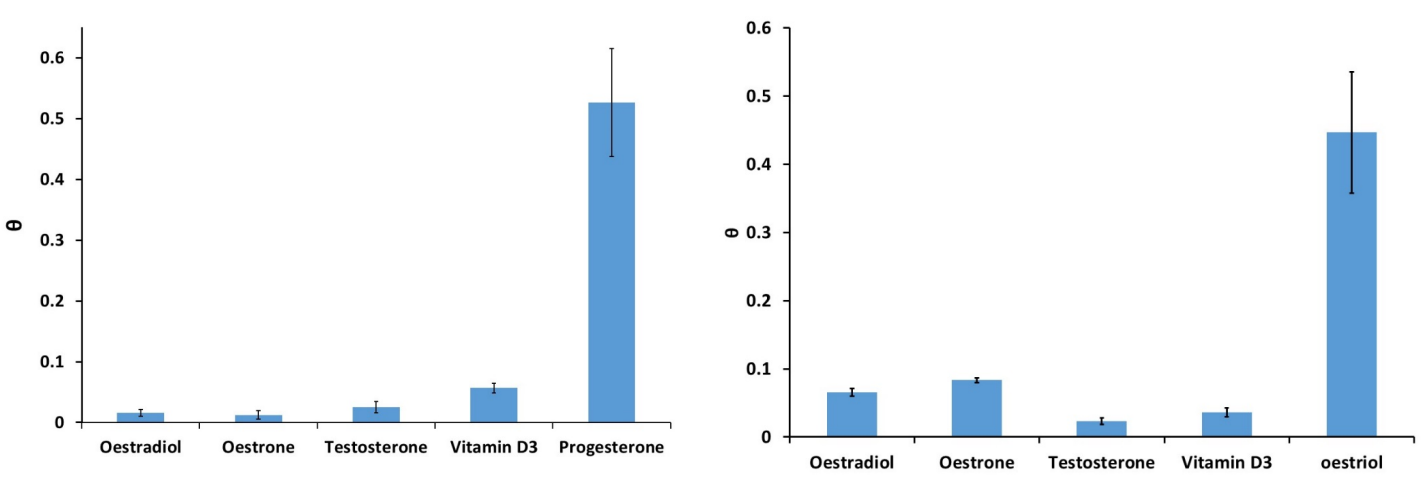

Figure 7: Interference studies of the visual immunoassay, using $20 \mathrm{ng} \mathrm{mL}^{-1}$ antigen concentration in PBS incubated for 30 min on the ferricenium-tagged antibody-modified surface (anti-progesterone antibody, a, left, or anti-œstriol antibody, b, right), followed by imaging observation of chemiluminescence using an $200 \mathrm{~s}$ exposure time with $10 \mathrm{mM}$ luminol, $10 \mathrm{mM}$ $\mathrm{H}_{2} \mathrm{O}_{2}$ and $0.1 \mathrm{M}$ aqueous $\mathrm{NaOH}$, and using equation (2) to determine blocking fractions. The error bars represent one standard deviation over three repeats.

Clearly, this system exhibits a marked selectivity for the target antigen, as expected for monoclonal antibodies, even though the antigens are small molecules. ${ }^{44}$ The data in Figure 7 were analysed in terms of a recovery test, 
using the data from Figure 6 (in PBS) as a crude, semi-logarithmic calibration curve. A $20 \mathrm{ng} \mathrm{mL}^{-1}$ spiked sample (Figure 7) afforded between 10-13 $\mathrm{ng} \mathrm{mL}^{-1}$ of progesterone or œstriol, yielding approximately 50\% recovery. Whilst this is a low recovery, this calibration is not optimised: the spiked sample contained potential interferences and the calibration curve from the data in Figure 6 could only be drawn to $10 \mathrm{ng} \mathrm{mL}^{-1}$. 


\section{Conclusions}

A novel and simple immunoassay has been developed employing surfacecatalysed luminol/hydrogen peroxide chemiluminescence, using ferroceneconjugated monoclonal antibodies, with the redox label in the oxidised state (ferricenium). In a manner equivalent to negative imaging in art, this imaging immunoassay gives rise to chemiluminescence intensities that decrease with increasing antigen concentration. The immunoassay demonstrates good reproducibility, and provides quantitative analysis in artificial saliva within a total analysis time of less than $45 \mathrm{~min}$ (from saliva sample acquisition to final result analysis) for both progesterone and œstriol. The inexpensive method of measurement, together with the non-invasive nature of saliva, and the marked selectivity for the target antigen, encourages the exploitation of this sensing protocol within biosensors in a point-of-contact setting, for example, to monitor female sub-fertility, since it reduces the risk of false positives from typical interferences in saliva.

\section{Acknowledgements}

GMG and KJW thank The University of Hull for financial support; ZOO thanks the Royal Embassy of Saudi Arabia for a PhD Scholarship; MMA thanks Taif University in Saudi Arabia for a PhD Scholarship; JDW thanks EPSRC (GR/N EP/G020833/1) for funding.

\section{Conflicts of Interest}

There are no conflicts of interest to declare. 


\section{References}

1. See, for example, D. Male, J. Brostoff, D. B. Roth, I. Roitt, Immunology, $7^{\text {th }}$ edn., Elsevier, Philadelphia, 2006.

2. F. McCapra, in A. P. F. Turner, I. Karube, G. S. Wilson (eds.), Biosensors: Fundamentals and Applications, Oxford University Press, Oxford, 1987.

3. O. Seitz, P. G. Fernandes, R. Tian, N. Karnik, H.-C. Wen, H. Stiegler, R. A. Chapman, E. M. Vogel, Y. J. Chabal, J. Mater. Chem., 2011, 21, 4384.

4. R. M. Pasternack, S. R. Amy, Y. J. Chabal, Langmuir, 2008, 24, 12963.

5. N. A. Lapin, Y. J. Chabal, J. Phys. Chem., 2009, 113, 8776.

6. L. C. Shriver-Lake, W. B. Gammeter, S. S. Bang, M. Pazirandeh, Anal. Chim. Acta, 2002, 470, 71.

7. Y.-H. Dou, S. J. Haswell, J. Greenman, J. D. Wadhawan, Electroanalysis, 2012, 24, 264.

8. L. I. Partington, S. L. Atkin, E. S. Kilpatrick, S. H. Morris, M. Piper, N. S. Lawrence, J. D. Wadhawan, J. Electroanal. Chem., 2018, 819, 233.

9. S. Ren, X. Wang, Z. Lin, Z. Li, X. Ying, G. Chen, J.-M. Lin, Luminescence, 2008, 23, 175.

10. Y.-H. Dou, S. Haswell, J. Greenman, J. Wadhawan, Electrochem. Commun., 2009, 11, 1976.

11. H. Obata, H. Karatini, E. Nakayama, Anal. Chem., 1993, 65, 1524.

12. W. R. Seitz, in M. A. de Luca (ed.), Methods in Enzymology, vol. 57, Academic Press, London, 1978, p.445.

13. R. Wilson, D. J. Schiffrin, Anal. Chem., 1996, 68, 1254.

14. R. Wilson, D. J. Schiffrin, J. Electroanal. Chem., 1998, 448, 125.

15. N. Ngamchuea, K. Chaisiwamongkhol, C. Batchelor-McAuley, R. G. Compton, Analyst, 2018, 143, 81.

16. E. C. Porto-Mascarenhas, D. X. Assad, H. Chardin, D. Gozal, G. de L. Canto, A. C. Acevedo, E. N. S. Guerra, Crit. Rev. Oncol./Hematol., 2017, 110, 62.

17. See, for example, V. E. Fantl, D. Y. Wang, R. E. Knyba, J. Steroid Biochem., 1982, 17, 125.

18. B. Priya, M. D. Mustafa, K. Guleria, N. B. Vaid, B. D. Banerjee, R. S. Ahmed, Brit. J. Obstet. Gynæcol., 2013, 120, 1003.

19. P. Arck, P. J. Hansen, B. Mulac Jericevic, M.-P. Piccinni, J. Szekeres-Bartho, Am. J. Reprod. Immunol., 2007, 58, 268.

20. V. D. Castracane, A. Flores-Villacrez, W. Meachum, C. G. Maguire, in Abstracts of the $96^{\text {th }}$ Meeting of the Endocrine Society, 2014, SAT-0102-SAT-0102.

21. Y. C. Lu, G. R. Bentley, P. H. Gann, K. R. Hodges, R. T. Chatterton, Fert. Steril., 1999, 71, 863.

22. R. F. Walker, G. F. Reed, D. Riad-Fahmy, Clin. Chem., 1979, 25, 2030.

23. J. K. Choe, F. S. Khan-Danood, M. Yusoff-Danood, Am. J. Obstet. Gynecol., 1983, 147, 557.

24. L. A. Perry, N. Wathen, T. Chard, Horm. Metab. Res., 1987, 19, 444.

25. J. J. Evans, A. R. Wilkinson, D. R. Alckin, Clin. Chem., 1984, 30, 120.

26. See, for example, D. M. Hardy (ed), Fertilization, Academic Press, San Diego, 2002.

27. M. S. Preti, S. Lodi, P. Busachi, M. Filicori, C. Flamigni, Steroids, 1984, 43, 469.

28. N. Kundu, N. Novak, L. P. Petersen, Steroids, 1983, 41, 145.

29. J. Darne, H. H. G. McGarrigle and G. C. L. Lachelin, Brit. Med. J., 1987, 294, 270.

30. I. I. Bolaji, Int. J. Gynecol Obstet., 1994, 45, 125.

31. C. E. West, J. L. Hardcastle, R. G. Compton, Electroanalysis, 2002, 14, 1470.

32. M. Okochi, H. Ohta, T. Tanaka, T. Matsunaga, Biotechnol. Bioeng., 2005, 90, 14.

33. A. Hawe, W. L. Hulse, W. Jiskoot, R. T. Forbes, Pharmaceut. Res., 2011, 28, 2302.

34. P. M. Prichard, M. J. Cormier, Biochem. Biophys. Commun., 1968, 31, 131.

35. M. J. Cormier, P. M. Prichard, J. Biol. Chem., 1968, 243, 4706.

36. J. Lind, G. Merényi, T. E. Eriksen, J. Am. Chem. Soc., 1983, 105, 7655.

37. L. Li, M. A. Arnold, J. S. Dordick, Biotechnol. Bioeng., 1993, 41, 1112.

38. P. Khan, D. Idrees, M. A. Moxley, J. A. Corbett, F. Ahmad, G. von Figura, W. S. Sly, A. Waheed, M. I. Hassan, Appl. Biochem. Biotechnol., 2014, 173, 333.

39. J. P. Hurvois, C. Moinet, J. Organomet. Chem., 2005, 690, 1829.

40. R. Prins, A. R. Korswagen, A. G. T. G. Kortbeck, J. Organomet. Chem., 1972, 39, 335.

41. M.-B. Gholivand, A. R. Jalalvand, G. Paimard, H. C. Goicoechea, T. Skov, R. Farhadi, S. Ghobadi, N. Moradi, V. Nasirian, Int. J. Biol. Macromol., 2014, 70, 596.

42. F. S. Khan-Dawood, J. K. Choe, M. Y. Dawood, Am. J. Obstet. Gynecol., 1984, 148, 442. 
43. Y.-C. Lu, G. R. Bentley, P. H. Gann, K. R. Hodges, R. T. Chatterton, Fert. Steril., 1999, 71, 863.

44. A. Saitman, H.-D. Park, R. L. Fitzgerald, J. Anal. Toxicol., 2014, 38, 387. 